\title{
Cargill's corporate growth in times of crises: how agro- commodity traders are increasing profits in the midst of volatility
}

\author{
Tania Salerno ${ }^{1}$
}

Accepted: 2 January 2016/Published online: 20 January 2016

(c) The Author(s) 2017. This article is published with open access at Springerlink.com

\begin{abstract}
This paper proposes two interrelated arguments: first, it is argued that agro-commodity traders are uniquely placed at the crossroads of agricultural trade to benefit from agricultural commodity speculation; and second, that the networks constituting their operations are central to their hedging activities. The case of Cargill-the largest privately owned company in the United States and one of the largest agricultural traders in the world-is used to support this argument by unpacking its operations, structure, and hedging strategies. In order to connect the operations of Cargill to its speculating strategies, this paper first traces how agriculture and finance have become increasingly intertwined leading to heightened agricultural commodity speculation. Second, Cargill will be positioned within this process by analyzing how it has financialized its own strategies and its Corporate Platform. Third, Black River Asset Management, Cargill's private equity arm, will be analyzed to show how it uses the information moving through Cargill's Platform to engage in hedging and/or speculation.
\end{abstract}

Keywords Speculation - Food crisis - Financialization · Global food system · Cargill

Tania Salerno

salerno.tania@gmail.com

1 Department of Anthropology, University of Amsterdam, PO Box 155081001, NA, Amsterdam, The Netherlands

\section{Introduction}

Between the years 2006 and 2008 commodity prices were characterized by volatility and unpredictability. Yet, as food prices rose and fell, some agricultural and financial actors saw record high profits and increased power over the global agricultural system. These included the "Four Giants" of agribusiness, also collectively known as the ABCD grain traders-that is, Archer Daniels Midland (ADM), Bunge, Cargill, and Dreyfus. This paper argues that this growth may be opportunistic and the result of access to important information regarding the global supply of agricultural products. As Meyer in the Financial Times, noted, "[p]hysical traders are often the first to know when crops are falling short or energy cargoes are interrupted, giving them the edge over others" (2011); implying traders are using inside access to information through their operations to take speculative positions in commodity markets (van Dijk et al. 2011). This paper builds on this argument and shows how commodity traders maintain access to important information and the possible implications for agro-commodity markets.

Cargill is the largest of the ABCD traders and is nearly twice the size of its publicly held rival in the food production industry, ADM (Whitford and Burke 2011). In 2008, when food prices peaked, Cargill reported peak earnings of $\$ 744$ million (Cargill 2008). Cargill itself has been open about its profits throughout the price swings. As Cargill explained in an annual report from 2009: "the insights gathered from many activities and places enabled our trading teams to avoid being stung by plummeting commodity prices" (Cargill 2009). It is argued here that Cargill does so through an information network supported by its Corporate Platform. This Platform is composed of seven main business units divided further into subunits 
(70 in total), each with access to various agricultural actors, companies, sectors, and privileged information regarding current and future supply, demand, and risk. Three of Cargill's 70 subsidiaries-Black River Asset Management, Cargill Risk Management, and Carval Investors-are involved primarily in finance investing in agricultural companies, funds, lands, and commodities. The subsidiaries have allowed Cargill to capitalize on the financialization of agriculture via financial investment in agricultural commodities, companies, and land (Salerno 2014). The financialization of agriculture refers to "the increased influence of finance capital on the agri-food system" which "not only provides new opportunities for profit-making by hedge funds and private equity consortia, but also creates a situation in which agrifood companies, including food manufacturers, international commodity traders and supermarkets, may benefit" (Burch and Lawrence 2009, p. 267).

Speculation in food commodity markets has come under fire recently with some scholars and activists claiming that it encourages food price swings (see Kerckhoffs et al. 2010). One side of the debate-taken by academics, economists, civil society, government departments, and development organizations-asserts that financial speculation is the underlying problem as financial actors swarmed agricultural markets driving up prices (see Kerckhoffs et al. 2010). Another stance-taken by financial actors, economists, and some large development organizations (such as the World Bank) - is that it is an issue of supply and demand. In short, increasing population and changing eating patterns, climate change, as well as various global geopolitical dynamics, has meant supply has not been able to meet demand and prices have moved accordingly (see Irwin et al. 2009). A third position is that it is a combination of both the implications of speculation as well as the various elements affecting the supply and demand of different commodities (such as transportation costs, gas prices, storage costs, government policies, etc.) (See De Schutter 2010). Cargill's position in the debate lies somewhere in the middle; employees have both claimed that volatility is the result of non-agricultural actors swarming financial markets, such as pension funds, equity funds, and sovereign wealth funds (Luyt 2013), while also arguing that " $[\mathrm{t}] \mathrm{here}$ has to be the speculators in the market...You cannot accuse speculators all the time, saying that they are causing all this mess. You need those speculators...you need those guys to give the liquidity to the market...you need the funds, you need the pension funds, you need the speculators" (Cargill employee quoted in Lander 2016). The above debate, while important for context, will not be elaborated upon here (see De Schutter 2010 for further discussion). Rather than contributing to this debate, this paper will analyze how agricultural speculation can be used by agro-commodity traders opportunistically with the case of Cargill.

This paper analyzes how Cargill benefits from agricultural price volatility using the Platform's networks, which act as conduits for information transmission from the farm gate to the market. van Dijk et al. (2011) describe how the sharing of agricultural supply information is based on a pivotal position in agricultural markets and can be used to "manipulate the market and profit from uncertainty". Isakson (2014) has likewise argued that much of the large traders' recent profits is connected to "their unique access to food suppliers" and "is also the source of information regarding global food stocks, giving them an advantage when hedging and speculating on price movements". Clapp (2014) furthers this argument with reference to all of the large agro-commodity traders:

The ABCD firms operate under a complex business model that involves dealing in bulk commodities and trading high volumes at typically low margins. Each of these firms is intimately linked to the world of complex agricultural commodity chains, with different aspects of their business touching all aspects of those chains from production to consumption. And each has privileged access to information that has helped them to maintain advantage over their competitors (p. 804).

Building on these arguments, this paper demonstrates how Cargill can profit from uncertainty through its highly advanced information sharing system that encourages Cargill employees and suppliers to share pivotal "on the ground" information throughout its networks. The case of their private equity fund, Black River, is analyzed to show how information on the ground links up with financial subsidiaries speculating and hedging in agricultural markets. This paper, therefore, focuses on the role of agrocommodity traders engaging in agricultural commodity speculation rather than primarily financial actors. This is important since the involvement of agricultural actors depicts how the structure of commodity markets empowers them to speculate more efficiently than financial actors. Cargill for example, one of the largest agro-commodity traders in the world, is uniquely positioned to make use of the information shared through its networks to speculate in financial markets. Financial actors, on the other hand, do not have direct access to this information, giving traders an edge in speculative activities. Perhaps most importantly, and most advantageous for Cargill, is the fact that this information sharing, which some have characterized as "insider trading" (see Murphy et al. 2012, p. 27), is legal and unregulated due to the structure of commodity markets.

In order to connect the operations of Cargill to its hedging or speculating strategies, this paper first traces how 
agriculture and finance have become increasingly intertwined leading to heightened agricultural commodity speculation. Second, Cargill will be positioned within this process by analyzing how it has financialized its own strategies. Third, Black River Asset Management, Cargill's private equity arm, will be analyzed to show how the company's subsidiaries feed information to its financial offices to inform hedging strategies and possibly speculative practices. Information is derived from fieldwork over a 12 month period in the Philippines, Singapore, and Indonesia amongst investors, government officials, national/local elites, land holders, business cliques, business organizations, and others. Details are derived from interviews and correspondence with Cargill employees, and secondary information regarding Cargill's operations.

\section{The financialization of agriculture and speculation in agricultural markets}

The financialization of agriculture is a relatively recent phenomenon that has emerged through various waves of deregulation. Starting in the 18th century, futures exchanges for agricultural commodities were established in London to allow farmers and grain traders to buy and sell commodities for a future delivery (Clapp 2014). This provided a form of risk management in a sector vulnerable to shifts in supply and demand, for example due to weather fluctuations. Future exchanges spread to various countries and trading in agriculture futures became common (Cronon 1991). Some of the exchanges, such as the Chicago Mercantile Exchange Group, have been regulated since the 1900s in order to control the possible manipulation of markets by taking large positions (Clapp 2014). This is what is now termed "market speculation", and will be discussed below.

Regulations were also used to monitor the uses of futures contracts. For example, the US Commodity Exchange Act, implemented in 1936, was implemented to manage speculation by non-commercial traders by controlling the amount of futures contracts they were allowed to hold at one time (Clapp 2014). The objective was to control sudden price shifts by preventing excessive speculation from non-commercial traders (Clapp and Helleiner 2012). In 1974 the Commodity Futures Trading Commission (CFTC) was established as an important tool to regulate futures markets, such as through position limits, in the US (Clapp 2014).

The regulations used to prevent market manipulation were slowly eroded from the 1980s onwards, making the connection between finance and agricultural products more complex and enabling different players to invest in agricultural commodities. In 2000 the Commodity Futures Modernization Act (CFMA) was implemented in the US, which allowed over the counter (OTC) derivative trading and speculation to occur more freely. Banks developed Commodity Index Funds (CIFs); which is a fund made up of various commodities, including oil products, livestock, minerals, etc. (Clapp 2014). In the current system, agricultural commodities make up about $1 / 3$ of all CIFs (ibid). CIFs allow banks to trade the financial derivative of a product to investors informally over the counter (Russi 2013) without ever trading in the actual physical commodity.

In short, the recent financialization of agricultural commodities coincides with the widespread deregulation of markets. As Isakson (2014) explains, "[i]nfluenced by the rise of neo-classical economics, particularly Milton Friedman's 'efficient markets hypothesis', states erected a 'New Financial Architecture' (NFA) that reflected the era's prevailing belief that minimal government regulation enables markets to generate efficient and socially optimal outcomes" (p. 4). The new approach to markets was based on "light regulation of commercial banks, and even lighter regulation of investment banks, and little if any regulation of the 'shadow banking system'-hedge and private equity funds and bank-centered Special Investment Vehicals" (Crotty 2009, p. 564). This meant that previously regulated financial actors or traditional agricultural players were enabled to consolidate large pools of investment funds, financial techinicians could develop new financial products, and new investment areas were able to be identitified (i.e. in land, agricultural derivatives, and agro-food enterprises) (Isakson 2014). Therefore, as the regulations that previously controlled agricultural markets were weakened, the nature of speculation in these markets changed as well.

Consequently, as commodity markets were deregulated, financial investments in agricultural land and companies also became common (Burch and Lawrence 2009). With the financialization of the world economy, financial institutions opened up funds to invest in various sectors. These funds were pooled to include the capital of different financial institutions (such as pension funds). The funds and financial branches that grew from the financialization of commodity markets looked towards other areas of investment, such as investing equity in agricultural companies, land, and output. At the same time, as agriculture became financialized, traditional agro-commodity traders opened up their own funds and financial firms which would allow them to engage in speculation. Traditional agricultural players-such as traders, producers, retailers, etc.financialized their strategies to keep their operations relevant and to expand financially within this context. Murphy et al. (2012) explain this further:

Traditionally, the food system involved producers (farmers) and a series of commercial interlocutors, who traded, processed, distributed, and sold food. Today, banks and other investors, as well as 
dedicated investment funds established as subsidiaries of the ABCDs themselves, have invested billions of dollars in food commodities with no interest in taking possession of any physical commodity. Their behaviour is intimately linked to what is happening in the physical trade of food, of course, but it also affects that trade by affecting process and behaviour (p. 6).

Therefore, whether it was purely financial actors going agricultural or agricultural actors going financial, the nature of the market that developed out of deregulation led to a transformation of the agricultural system, which can be broken into three categories: commodities, companies, and land. All three are interlinked, however for the purposes of this paper the former two will be of central focus here.

Agricultural commodities have long been linked to speculation; however, the current extent of this speculation is a new phenomenon. Agricultural commodity speculation, simply put, involves betting on fluctuating prices. Today, the intention is to maximize advantages with fluctuations in the market. Traditionally, however, commodity speculation was actually used as a protection for the agricultural sector. Since the 19th century it was thought to enable commodity traders and processors to protect themselves against short term price volatility (Institute for Agriculture and Trade Policy 2008). For commodity buyers and sellers, commercial speculation has been a form of price insurance. This started to change when markets were opened up due to the aforementioned policy changes. It is argued that, as more actors became drawn to agricultural markets, prices started to become unstable. There are many types of speculation, each with its own implications, some considered negative and some positive. Table 1 outlines a useful categorization proposed by Spratt (2013) on four main types of speculation. This categorization helps to understand the different uses and implications of speculation.

The fourth category-market speculation-is considered to be the most controversial form of speculation. With this form of speculation, non-traditional speculators have increasingly started participating in the derivatives markets and "have been (re-)buying and (re-)selling all kinds of derivative contracts with agricultural commodities and derivative contracts as underlying assets" (Kerckhoffs et al. 2010, p. 3), which is what some argue causes food price volatility and possible food crises. In these cases, the motivations are purely financial with little interest in the implications of their investments or knowledge about the underlying commodities they are speculating on (Spratt 2013). These actors include hedge funds, pension funds, other institutional investors and large banks, often investment banks, operating as dealers (offering and entering into derivative contracts).

The first category is the more traditional form of speculation, discussed earlier, which was used as a safeguard for farmers. This is still used today and is provided as a risk management tool by large agricultural firms and banks. Cargill Risk Management could engage in all four types of hedging depending on the client. For example, type 1 (Natural Independent Hedging) can be used for Cargill's smaller clients like large farm owners in North America, while type 3 (Natural-Independent Speculation) and 4

Table 1 Spratt's categorization of financial speculation

\begin{tabular}{|c|c|c|}
\hline Type & Explanation & Impacts \\
\hline (1) Natural-independent hedging & $\begin{array}{l}\text { This form of speculation is based on the need to } \\
\text { mitigate risk related to uncontrollable events, such } \\
\text { as weather }\end{array}$ & $\begin{array}{l}\text { Is considered to have a positive consequence since it } \\
\text { allows for financial insurance in uncontrollable } \\
\text { situations, such as insuring one's home against a } \\
\text { fire }\end{array}$ \\
\hline (2) Market hedging & $\begin{array}{l}\text { This form of speculation is based on the need to } \\
\text { mitigate risk related to market movements }\end{array}$ & $\begin{array}{l}\text { Impacts are "contingent upon the structure of the } \\
\text { market..." which is "...partly a result of policy } \\
\text { actions (and inactions)" (Spratt 2013, p. 7, } \\
\text { emphasis added) }\end{array}$ \\
\hline $\begin{array}{l}\text { (3) Natural-independent } \\
\text { speculation }\end{array}$ & $\begin{array}{l}\text { Actors engage in this form of speculation to "profit } \\
\text { from outcomes in the natural-independent hedging } \\
\text { market-e.g. weather-influenced securities or } \\
\text { insurance markets" (Spratt 2013, p. 7, emphasis } \\
\text { added) }\end{array}$ & $\begin{array}{l}\text { Most negative impacts are restricted to the actor } \\
\text { taking the risk }\end{array}$ \\
\hline (4) Market speculation & $\begin{array}{l}\text { Actors engage in this form of speculation in order to } \\
\text { make a profit from movements in the market they } \\
\text { are speculating on, such as agricultural commodity } \\
\text { markets }\end{array}$ & $\begin{array}{l}\text { There are both positive and negative impacts. } \\
\text { Positive: providing liquidity and reducing hedging } \\
\text { costs. Negative: related to "potential amplification } \\
\text { of volatility and so the increased need to hedge } \\
\text { market risks" (Spratt } 2013 \text {, p. } 8 \text {, emphasis added) }\end{array}$ \\
\hline
\end{tabular}

Source: Spratt 2013 
(Market Speculation) are provided as a service to larger customers like pension funds. ${ }^{1}$ This will be discussed further in the next section. What must be emphasized here is how, as agriculture became financialized, traditional agricultural players opened up their own funds and firms, allowing them to engage in all the forms of speculation listed above. These fundamentals likely encouraged traditional agricultural traders, such as Cargill, to open up financial bodies allowing them to engage in market speculation.

Agricultural companies are connected to financialization in two primary ways: the first relates to larger agro-commodity traders opening financial arms and utilizing financial strategies to expand operations and the second relates to acquiring equity in smaller agricultural companies for the return on investment. Under this new financialized agricultural model, traditional agro-commodity traders began acting more like a bank rather than solely as an agricultural trader. As Clapp explains, "[t]apping into rising investor demand for commodity derivative financial products, the large agricultural commodity trading firms also began to get into the business" (2014, p. 803). However, in many cases it is now difficult to tell the difference between a financial actor and an agricultural one as, "[t]he distinction between banks and commodity trading firms has become increasingly blurred since the mid-1990s as both sets of actors became actively engaged in selling OTC agricultural commodity derivatives products such as commodity index funds and other OTC financial derivative products" (Clapp 2014, p. 804). They have done so by opening up different financial subsidiaries which in turn invest in commodities, land, and agricultural companies. Larger agricultural corporations, agro-commodity traders especially, and financial institutions have started investing in equity in smaller agricultural companies in an attempt to gain control over agricultural production and supply (Salerno 2014). For example, a private equity firm can acquire stakes in a company using an established fund. Once they have done so they can expand operations and possible secure supply. This will be discussed further in the next section with the case of Cargill.

\section{The Cargill Platform and access to information as a hedging strategy}

\section{The transformation and financialization of Cargill}

Cargill was founded in 1865 in the US by William Cargill and has remained in the family's hands ever since. The company has long since traded agro-commodities on the

$\overline{1}$ Interview with Cargill employee A, 18/10/2010. market and was a member of the Chicago Board of Trade since 1935. In the early years Cargill was involved mostly as a trader-collecting, storing, and shipping grain and other commodities around the US (Kneen 2002). The company built grain elevators at important points along the railways of Minnesota and Wisonconsin (ibid). Since then, the company has been in constant transition-moving to new regions when it became possible, diversifying the commodities traded, reorganizing the company structure, financializing its strategies, all while remaining privately owned and controlled by the Cargill family. Cargill has also consistently based its strategies on a network built on the physical trade of commodities and the movement of information. This information moves through a complex web of networks comprising the Cargill Platform.

Today Cargill has operations controlled by various branches and subsidiaries in 68 different countries. In addition to this they also have many joint-ventures headed by their subsidiaries. It has evolved into a global enterprise composed of seven different business segments which are subdivided further into business units and subunits. This structure is what they call the Cargill Platform. It is made up of: (1) Cargill agricultural supply chain (17 business units—one being the palm oil company CTP Holdings) ${ }^{2}$; (2) Cargill animal nutrition (two business units); (3) Cargill animal protein and salt (13 business units); (4) Cargill energy, transportation, and metals (five business, including a shipping company, a petrochemical company, and more); (5) Cargill financial services (two units, one being Cargill Risk Management); (6) Cargill food and ingredients and systems (26 units); and finally, (7) business units maintained but not associated with the Platform (including the fund Black River Asset Management, Carval Investors, and the land management agency, amongst others). ${ }^{3}$

Several of Cargill's subsidiaries are now financial or are in part connected to its financial operations. Three of the most important financial subsidiaries include Black River Asset Management, Cargill Risk Management, and Carval Investors-each uses the company's first-hand knowledge of commodity markets and the Platform's networks to inform decisions on a range of financial instruments including arbitrage, speculative trading, and equity positions. ${ }^{4}$ Black River Asset Management is an equity management firm working in company equity and index products in food, agriculture, clean energy, and metals/ mining. ${ }^{5}$ Carval Investors works with distressed and credit

\footnotetext{
${ }^{2}$ Within this sector the commodities traded include: cotton, palm oil and its derivatives, sugar, grain, oilseed. They also trade in meats, cocoa in other subunits.

${ }^{3}$ Outline provided by Cargill employee in an interview, 18/10/2010.

${ }^{4}$ Interview with Cargill employee A, 18/10/2010.

${ }^{5}$ Interview with Cargill employee A, 18/10/2010.
} 
Table 2 Cargill's privately held subsidiaries grouped by activities

\begin{tabular}{llll}
\hline & Black river & Carval investors & Cargill risk management \\
\hline Companies & $\begin{array}{l}\text { Invests in agricultural company } \\
\text { equity } \\
\text { Commodities }\end{array}$ & $\begin{array}{c}\text { Distressed and credit-intensive } \\
\text { assets }\end{array}$ & \\
& Index products & & $\begin{array}{c}\text { Hedging products (for corporations), } \\
\text { producers solutions (for capitalist } \\
\text { farmers), and products for clients (such } \\
\text { as pension funds) }\end{array}$ \\
Land & $\begin{array}{l}\text { Through agricultural company, } \\
\text { invests in land and production }\end{array}$ & Real estate investment & Asset classes: Loan Portfolios, \\
Info. On funds & $\begin{array}{l}\text { Approx. 15 funds in food, } \\
\text { agriculture, clean energy and } \\
\text { metals/mining }\end{array}$ & and Special Opportunities & \\
& &
\end{tabular}

Source: Author's own elaboration

intensive assets in loan portfolios, corporate securities, real estate, and special opportunities. Cargill Risk Management engages in market speculation on behalf of corporations and financial bodies (such as funds), and engages in natural independent hedging (type 1) for large farmers. Cargill's risk management firm invests in agricultural risk for customers such as pension funds wanting to invest in agriexpenses (type 3 and 4). ${ }^{6}$ They do so by focusing on when and how to hedge using financial instruments to manage exposure to risk through OTC swaps, ${ }^{7}$ exchange cleared swaps, futures, and commodity linked notes in commodity markets such as corn, wheat, soybean, vegetable oils, livestock, etc. ${ }^{8}$ Cargill Risk Management and Black River engage in both proprietary trading on behalf of Cargill as well as providing financial strategies for customers. ${ }^{9}$ However, the amount that proprietary trading activities contribute to Cargill's profits and internal revenues is beyond the scope of this paper. Each subsidiary contributes to the various objectives of Cargill using diverse types of financial strategies with different connections to agriculture. Table 2 outlines the different forms of involvement in agriculture of each subsidiary and the financial strategies used.

Each of these financial subsidiaries represents an important element of the financialization of Cargill's operations, and highlight just how important finance has become for the company. The exact amount that each of these firms contribute to Cargill's profits is difficult to discern and requires further analysis. However, Murphy et al. suggest that a majority of profits come from their

\footnotetext{
${ }^{6}$ Interview with Cargill employee B, 18/10/2010.

7 A swap involves 'the exchange of one asset or liability for a similar asset or liability for the purpose of lengthening or shortening maturities, or otherwise shifting risks' (Irwin and Sanders 2010, p. 5).

${ }^{8}$ Interview with Cargill employee B, 18/10/2010.

${ }^{9}$ Interview with Cargill employee A and B, 18/10/2010.
}

financial activities, including "financial speculation on agricultural commodity markets and index funds, transportation, and storage" (2012, p. 11). In fact, since Cargill began financializing its strategies, the company has not only grown but has flourished (Murphy et al. 2012), leading some to question whether financial activities are currently even more important for profits than the trade of actual commodities. For example, Lander notes that the argument raised by Murphy et al. (2012) infers "access to information about supply and demand, and the volatility of the markets, especially early information, is more important to the traders than the actual trading of commodities" (Lander 2016). Whether this is true or not is beyond the scope of this paper, but it highlights the need for a more systematic analysis of the role of each financial branch in the growth and expansion of Cargill, and what this means for agrocommodity markets.

Due to the operations and positioning of Cargill, via its dominance over agricultural trade and its position with suppliers and commodities, its operations were, and continue to be, highly attractive to investors who would like to speculate on agricultural derivative markets. Cargill itself is capitalizing on its position and has been amongst the biggest winners of the large agro-commodity traders from the transition. The corporate structure not only diversifies its activities, it expands and deepens its knowledge making it both the producer and supplier of agricultural commodities as well as the actor speculating on those same commodities' price fluctuations on agricultural markets. Cargill's Platform touches almost every element of agricultural production and consumption globally. This provides the company with first-hand knowledge of commodity markets which inform the company's financial strategies, including arbitrage, speculative trading, and equity positions. The next section will address the company's positioning and how this position is used to inform speculative activities. 


\section{The "economic intelligence" of the Cargill Platform}

Cargill's economic intelligence is shaped by its Corporate Platform, which "employs a large international network of intelligence-gathering operatives, all plugged in electronically to the company's French chateau-style headquarters in the Minneapolis suburb of Minnetonka. Weather, crop, price, currency, market, and political data pour in daily from around the world for interpretation by Cargill traders and managers" (Ahlberg 2014). Cargill has been employing a highly advanced information sharing technique since around the 1920s, when the company implemented its "private teletype system, called 'the wires"” which was used "...to transmit intelligence to and from its far-flung offices" (Davis 2009). Due to technological advances, Cargill's techniques on information gathering and sharing have, of course, evolved tremendously. In fact, the former U.S. Secretary of Agriculture, Bob Bergland, described the company's present-day ability to acquire political and economic intelligence as exceeding that of the Central Intelligence Agency (Ahlberg 2014).

Due to Cargill's real-time insight into various markets the company has been described as the "Goldman Sachs of commodities trading" (Lippert 2011). These insights are derived from information flowing through the Platform's networks, aiding Cargill's sub branches to decide on "investment strategies on agricultural markets." 10 These investment strategies are derived from Cargill's access to privileged information regarding current and future supply, demand, and risk, while also giving them an edge on future price fluctuations through the Cargill network. The Platform's networks provide Cargill with a powerful market position reaching various elements of the agricultural system-they are not only commodity traders; they operate at all levels of the commodity chain from "farm to plate". As the company describes in a corporate brochure from 2001:

Cargill is an international marketer, processor and distributor of agricultural, food, financial and industrial products and services.

We are the flour in your bread, the wheat in your noodles, the salt on your fries. We are the corn in your tortillas, the chocolate in your dessert, the sweetener in your soft drink. We are the oil in your salad dressing and the beef, pork or chicken you eat for dinner. We are the cotton in your clothing, the backing on your carpet and the fertilizer in your field (quoted in Kneen 2002).

In other words, Cargill is not simply a part of the chain, "they are the chain" (Lippert 2011). The Platform constitutes a complex web of networks which connects

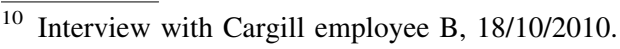

all of Cargill's branches, subsidiaries, holdings, and acquisitions. These networks provide Cargill access to on the ground information around the world by connecting their various branches, joint-venture partners, supplies, customers, etc.

Information is therefore mainly shared through their contacts on the ground working in, for, and with, the above mentioned subsidiaries. In fact, according to van Dijk et al. (2011), Cargill's employees "count competitors' trucks at the gates of almost every cocoa warehouse in the port of Abidjan in Ivory Coast to get a better picture of the size of the country's output" (p. 3). Therefore, local counterparts track the operations of others and feed the information back to the financial subsidiaries in Singapore and other financial hubs. Information also flows through Cargill's World Trading Unit in Geneva, where analysts track shipping activities around the world, catalogue commodity movements, and share information with other branches (Davis 2009).

This strategy forms the basis of how Cargill has used financialization to expand its presence. The power of the Cargill network for information gathering and how this power is strengthened through the acquisition of national companies is best examined through the case of Cargill's acquisition of the Australian Wheat Board (AWB) trading and origination arm and GrainFlow storage and handling business in 2011. AWB employs a network of 40 grain marketers in 26 locations throughout Australia (ibid); therefore, through the acquisition Cargill gained access to information regarding the supply of grain throughout Australia, allowing employees to process the information through their networks and inform their hedging strategies.

Cargill is open about the significance of inside knowledge to their success partly because it is a main attraction for institutional investors. As they have explained, "[c]learly the volatility can be an opportunity" (Whitford and Burke 2011); since Cargill knows how to prepare and benefit from sharp price swings. This is not a natural occurrence, but a result of business strategizing and specific market positioning. In fact, Black River's website explains that "our strategies benefit from our extensive worldwide footprint and decades of experience trading in developing countries; and Black River commodity-related strategies reflect our deep knowledge, and relationship to our parent, Cargill" (Black River Asset Management 2014). Employees of Cargill have stated that the company has a history of engaging in the stock market based on "the knowledge of what is in short supply and what is not" since "this kind of information is very valuable for a hedge fund because you know where to invest, when, and how much." 11

\footnotetext{
${ }^{11}$ Interview with Cargill employee B, 18/10/2010.
} 
The strong position of Cargill has attracted institutional investors to Cargill's financial branches. This is for various reasons, first because of the strong fundamentals of agricultural markets; second, because of the (sometimes) weak fundamentals in other markets; third, because Cargill has access to the relevant information needed to invest in these markets; and fourth, although they are using insider knowledge it cannot be considered insider trading because of the structure of commodity futures markets.

The fourth attraction listed is very important, since essentially it ensures that commodity traders are allowed to maintain their superiority in agricultural markets. In short, there is no legal barrier which hinders the sharing of information to protect against insider trading in agricultural commodity markets. Therefore, the very structure of commodity markets is built in a way that benefits Cargill's hedging strategy by allowing for insider information sharing while the structure of the Platform's network is what gives the company an edge over other speculators, making them one of the best positioned to speculate on agricultural markets. Black River Asset Management provides a useful example as to how Cargill has responded to the design of futures markets to allow them to use information to speculate.

\section{Black River Asset Management and the information network}

\section{Information pathways}

From 1984 to 2003 Black River Asset management was listed as Cargill's Global Capital Markets Division with the main function to engage in proprietary trade for Cargill. Propriety trading involves trading in financial instruments derived from the fund's capital rather than that of customers-using stocks, bonds, commodities, derivatives, and currencies. Black River was initially established based on Cargill's business model and to make use of the knowledge Cargill had regarding crop fluctuations (Salerno 2014). As one employee stated, this information defined their hedging strategy since it provided them privileged information regarding "what kind of commodity to buy at what price" (Salerno 2014, p. 1719). In other words, Black River was initially established with the main purpose to invest using the information derived from other branches regarding crop shortages and surpluses. Today, it engages in two key mechanisms: (1) Absolute Return Trading Strategies, which involves investing in financial instruments; and (2) Private Equity Strategies, which consists of investing in companies. Financing is derived from large financial investors such as pension funds, endowments, and foundations, for whom it manages over $\$ 4.5$ billion USD in assets (ibid).
In 2008, when financial actors began gravitating towards agriculture as a financial investment, Black River established an Asian Food Fund, worth over \$455 million USD. This fund received capital from various institutional investors including the Dutch Pension fund PGGMaround $€ 50$ and $€ 100 \mathrm{~m}$ (Alt Assets 2015)_and the Teachers' Retirement System of the State of Illinoisaround $€ 60 \mathrm{~m}$ (Shieber 2013). This fund focused on the equity acquisition of suppliers (or possible suppliers) of Cargill, allowing Black River to invest in a company while simultaneously investing in land and supply (Salerno 2014). The objective of the fund is to boost the output of Cargill's suppliers through capital input into a national company from Black River to increase production. ${ }^{12}$ Interestingly, Cargill does not directly control land or run on-farm operations in these arrangements. Rather it is indirectly controlling production through the acquisition of a company's equity. ${ }^{13}$ This highlights the importance of control over commodities and information regarding these commodities for Cargill, rather than the land itself, discussed briefly below.

Black River often selects companies through the Platform's networks, composed of the network of each employee and the companies that Cargill works with in each national context. ${ }^{14}$ As one employee of Black River described regarding selecting companies to acquire equity: "we use our Cargill network. Cargill has a lot of customers in our sectors we are interested in." ${ }^{15} \mathrm{He}$ also explains that if they can't find a company through formal contacts they can also go "through friends too of course." 16 Therefore, Cargill first distinguishes its suppliers who are not able to meet the demands of Cargill, and then has Black River invest in the company to boost their output, and finally (in most cases) the company in turn sells back the increased supply to Cargill. As one employee explained,

For example, if they [Cargill business unit] are selling to a shrimp feed company, but the company is not able to grow enough for Cargill, mainly because it can't find enough funds, Cargill will approach us [Black River] and tell us if we are interested to look into this company. Then we help them to grow. Then Cargill can get more product from them. So in this situation it's a win-win-win. ${ }^{17}$

\footnotetext{
$\overline{12}$ Interview with Cargill employee B, 18/10/2010.

${ }^{13}$ Cargill is directly involved in land control in its oil palm operations, organised under Cargill Tropical Palm (CTP) Holdings.

${ }^{14}$ Interview with Cargill employee B, 18/10/2010.

15 Interview with Cargill employee B, 18/10/2010

16 Interview with Cargill employee B, 18/10/2010.

${ }^{17}$ Interview with Cargill employee B, 18/10/2010
} 
The investments act as a triple benefit for Cargill and Black River: first, Cargill benefits from access to steady supply; second, by acquiring a stake in this national company they establish access to information; and third, Black River financially benefits through the equity sale. By controlling these companies through private equity Cargill gains further access to inside knowledge regarding crop supply, which provides them with information to speculate on. In short, these investments establish sources of information on the ground.

Even if it isn't the company itself that has direct access to the knowledge through a growth in operations, the actors on the ground are able to follow the operations of other companies nearby. Take the words of Jeff Drobny, chief investment officer of Black River:

We have very unique visibility into a broad set of commodities...genetics, the seeds that are being sold to farmers, fertiliser, where it's going and how much, all the way through that partial and total supply chain to when do they plan to harvest, where they plan to sell, where is the origin of certain commodities, what is the destination.

When we see something and have visibility into something that the market is not focused on, there lies the opportunity. It is important to emphasise how unique our visibility to the fundamentals is, what we do within that and how we capitalise on opportunities (Lindsey 2013).

In other words, Black River has a window into various commodity markets which allows them to act before anyone else. Based on the information available to their network and what is available to the actual market or to the USDA, they can synthesize "what external market consensus says, matching that with USDA forecasts" and then comparing this to an internal analysis (Lindsey 2013). In short, the strategy is to use, "cross-team collaboration, with information gathered from across global networks and an open dialogue to filter the best ideas, identify trends and evaluate risks" (Lindsey 2013). In the words of Black River:

We spend an enormous amount of time analysing the fundamentals of the market, collecting data, watching and discussing the cash markets and collaborating with Cargill to understand the fundamentals for those specific markets where we share information and share points of view. We have access to a lot of [Cargill's] research with respect to those specific money markets (Lindsey 2013).

It is one thing to have access to information, it is another to have a network established which encourages the flow of information to those that can use it for the benefit of
Cargill's financial strategies. One way Cargill ensures information makes it to the right actors is by providing bonuses to employees. In a Wall Street Journal report, Davis (2009) suggested that "the company adjusted its pay system a few years ago to reward agribusiness units and traders for advising each other about crop-disease outbreaks or shifting demands of fast-food chains. Pay is based partly on revenue generated by tips like these". This infers that Cargill pays its employees from its various subsidiaries in different countries around the world to share the information on supply to its financial arms in order to invest accordingly. The question then is how Black River may be using the information passing through Cargill's networks to speculate.

\section{The Black River strategy: manipulating the market or simply profiting from uncertainty?}

Within Cargill's global network-composed of subsidiaries, joint-venture partners, suppliers, clients, etc.information is constantly moving from sources on the ground to speculators in financial offices, allowing them to act before others through their inside edge. An example of how information from Cargill's structure and network is used by Black River is "the perfect storm" of 2012. Black River calls it "the perfect storm" because there were "crop losses of enormous magnitude in all three major exporting regions and countries in the world" (Lindsey 2013). In the spring of 2012 the South American soya bean crop was partially lost, then in the summer of 2012 the North American corn, and later the European wheat crop (Lindsey 2013). Therefore, the most significant exporters of grain and feed stuff in the world experienced problems with crops simultaneously, leading to extreme price movements. As an employee of Black River explained:

We perceived what was happening in the spring with soya beans. We sensed that it was happening in corn in the first part of June and we also picked up on the fact that it was happening in Europe, also in the latter part of June. The portfolio was positioned long all three markets. We were long in our wheat, corn, and soya beans (Lindsey 2013).

This implies that the company took a long position and invested in the likelihood that the price would go up rather than down, and in turn benefitted from it when prices acted accordingly. The employee goes on to explain how this is an example of how Black River's "visibility" into national contexts is important for their financial strategies: "We had visibility through our knowledge of North American corngrowing conditions from what we could perceive to be in the field and on the ground and with what we knew had already occurred in South America" (Lindsey 2013). 
Therefore, with knowledge regarding likely future commodity prices-derived from their onsite visibility-Black River took the appropriate (long) position, and when the crops mirrored their financial decisions they benefitted.

To summarize, the information regarding harvests is acquired by Cargill daily from various sources on the ground and channeled through the relevant businesses, then analyzed by a team of financial analysts, and finally their speculative positions can be made. Murphy et al. argue accordingly that the "significant advantage" of agro-commodity traders regarding access to information, "makes volatility important: they know better than most what supply and demand are likely to be, and they make big investments every year in financial markets, using this knowledge to full effect. Volatile prices are good for knowledgeable speculators" (2012, p. 12). In other words, food price volatility can be beneficial for commodity traders. This is not to say that traders are causing price volatility but that they are certainly benefitting from it. Therefore, it is possible that access to information regarding supply is as important, if not more so, than the physical crop itself (Murphy et al. 2012). This would imply that agro-commodity traders may be concerned less about the traded commodity and more about the information regarding the commodity. Whether or not this is true is difficult to say, however it is clear that speculation has become a vital element of the Cargill strategy that allows them to continually grow and does so through the expansion of its own Corporate Platform. Therefore, as the company grows financially through its speculative activities it simultaneously expands its involvement in the agricultural system. Therefore, Cargill itself may not be directly causing food price volatility, but they are likely benefitting from it via the financialization of the agricultural system.

It is important to end with a note on how regulation has been changing in recent years, which may impact Cargill's speculative activities. In 2013 the Dodd-Frank Act was implemented in the US which aims to reform the US financial sector. One regulation in Section 737 (4) of the Act was proposed to ensure the CFTC (Commodity Futures Trade Commission) establishes "limits on the amount of positions, as appropriate, other than bona fide hedge position, that may be held by any person with respect to contracts of sale for future delivery or with respect to options on the contracts or commodities traded on or subject to the rules of a designated contract market" (United States House of Representatives 2010). The intention of the limits is to "diminish, eliminate, or prevent excessive speculation", and to prevent market manipulation (United States House of Representatives 2010). The regulation has yet to be enacted and is still open for comment with the CFTC. It has received pressure from the International Swaps and
Derivatives Association (ISDA) to weaken the legislation, so it is yet to be seen if it will be implemented. However, the Dodd-Frank Act has already had some implications for Cargill, the biggest of which has been felt mainly by Cargill Risk Management since they now have to register as a swap dealer. One employee has explained that the biggest impact has been on Cargill Risk Management's clients, since they must now also comply with the DoddFrank rules as well making them hesitant to expose themselves. ${ }^{18}$ This is connected to older policy-discussed previously-that manages swap activities. Since Cargill Risk Management must now register as a swap dealer due to the Dodd-Frank Act, these previous policies now apply to Cargill as well. However, the position limits rule of the Dodd-Frank Act has yet to be enacted and if the rule goes through, the position limits might change further. Black River, on the other hand, has apparently not been impacted by the regulation due to the structure of their funds, which exempts them from registering. ${ }^{19}$ While the Dodd-Frank Act establishes limits and has hindered some of Cargill Risk Management's activities, it does not influence the way information is shared between Cargill's networks, meaning they may still maintain an edge over other actors regardless of the regulation.

\section{Conclusion}

This paper has argued that Cargill is able to both benefit from, and engage in, speculation through the company's corporate structure and privileged access to information regarding supply. Cargill's operations were presented to analyze how they have financialized their strategies by opening up various financial braches and how their connections on the ground feed information to the financial arms to inform hedging strategies. The case of Black River depicts how the network of Cargill allows them to expand their involvement in the agricultural system and capitalize on their knowledge and experience to exploit commodity markets to secure profits for themselves beyond simple hedging. It was argued that, although Cargill is using inside knowledge to speculate, it is not considered insider trading, making their activities legal and unregulated. This is due to the very structure of commodity markets, making Cargill's activities an opportunistic response to the way different markets have been designed. Therefore, for Cargill it is likely that speculation has been a resourceful response to the financialization of agriculture and their strategic

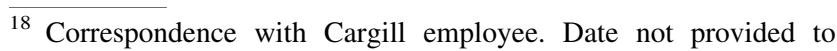
protect identity of the employee.

${ }^{19}$ Correspondence with Cargill employee. Date not provided to protect identity of the employee.
} 
positioning at the crossroads of the agricultural system. The position and involvement of Cargill and Black River in agricultural speculation shows how Cargill is essentially behaving like a financial firm while utilizing their unique positioning in the agricultural system and exploiting the opportunities made possible by agriculture's 'financialisation in reverse' (Burch and Lawrence 2009, p. 276).

This paper has undergone a preliminary discussion of this 'financialization in reverse', with respect to the role of agricultural traders in speculation. Future research should be undertaken to delve deeper into the debate to address whether agricultural traders do in fact influence, manipulate, and/ or control agricultural markets and food prices. Clearly, as more and more financial actors sell off their commodity branches, traders are taking a more centralized role in the financialization of agriculture. However, this cannot be clarified without a more thorough analysis of commodity markets and the actors dominating them. To further expose these dynamics it is important to analyze the level and extent of the financialization of traders, such as Cargill, and whether the profits from financial activities have surpassed that of trading activities. This would help clarify whether Murphy et al. (2012) are right to hypothesize that in the current financialized agricultural system, the information itself is more lucrative than the actual trading of commodities.

The debate would also benefit from an extensive quantitative analysis on the financial operations of agro-commodity traders. Future research into different financial activities of Cargill alone could reveal important information on speculating in agricultural commodity markets. For example, the different types of hedging used by Cargill's branches, the share of these branches in commodity hedging for certain crops, and the implications of each, could shed light on the level and type of influence of Cargill's operations on commodity markets. To make the analysis more intricate it could also be revealing to distinguish the level (and type) of proprietary trading versus trading on behalf of clients in each firm's financial branch.

However, acquiring most of this data can be very difficult, especially with privately listed firms. One solution is to undergo a comparative analysis of different cases of publically listed agro-commodity traders, such as ADM. Since publically listed traders are required to share a certain level of information regarding their different activities and operations, this could address gaps in the research on Cargill in particular. Researching agro-commodity traders and the financialization of agriculture can be very difficult due to barriers in access to information. However, all of these aforementioned possible research paths are crucial to explore in order to gain more insight into the changing scope of the agricultural system, the possible impact on food prices, and the place of agro-commodity traders in all of this.
Acknowledgments This paper is based on fieldwork from a research program funded by NWO-WOTRO called "(Trans)national Land Investments in Indonesia and the Philippines: Contested Control of Farm Land and Cash Crops". I am very grateful for the support of the Netherlands Organisation for Scientific Research (NWO), Science for Global Development (WOTRO) and to the program coordinators, Rosanne Rutten and Gerben Nooteboom. I appreciate the guidance and suggestions provided by the reviewers of this paper.

Open Access This article is distributed under the terms of the Creative Commons Attribution 4.0 International License (http://crea tivecommons.org/licenses/by/4.0/), which permits unrestricted use, distribution, and reproduction in any medium, provided you give appropriate credit to the original author(s) and the source, provide a link to the Creative Commons license, and indicate if changes were made.

\section{References}

Ahlberg, B. 2014. Cargill: Invisible giant. Multinational Monitor. http://www.multinationalmonitor.org/hyper/issues/1988/07/ mm0788_09.html. Accessed 12 May 2014.

Alt Assets. 2015. PGGM commits to Black River food fund 2. https:// www.altassets.net/private-equity-news/by-news-type/fund-news/ pggm-commits-to-black-river-food-fund-2.html. Accessed 10 Feb 2015.

Black River Asset Management. 2014. Black River investment strategies. https://www.black-river.com/strategies. Accessed 8 Oct 2014.

Burch, D., and G. Lawrence. 2009. Towards a third food regime: Behind the transformation. Agriculture and Human Values 26: 267-279.

Cargill. 2008. Cargill reports fourth-quarter and fiscal 2008 earnings. Cargill press releases. http://www.cargill.com/news/releases/ 2008/NA3007599.jsp. Accessed 10 Feb 2014.

Cargill. 2009. Annual Report. Cargill.

Clapp, J. 2014. Financialization, distance and global food politics. Journal of Peasant Studies 41(6): 797-814.

Clapp, J., and E. Helleiner. 2012. Troubled futures? The global food crisis and the politics of agricultural derivatives regulation. Review of International Political Economy 19(2): 181-207.

Cronon, W. 1991. Nature's metropolis: Chicago and the Great West. New York: W. W. Norton \& Company.

Crotty, J. 2009. Structural causes of the global financial crisis: A critical assessment of the 'new financial architecture'. Cambridge Journal of Economics 33(4): 563-580.

Davis, A. 2009. Cargill's inside view helps it buck downturn. The Wall Street Journal. http://www.wsj.com/articles/SB123189501 407679581. Accessed 16 Jan 2014.

De Schutter, O. 2010. Food commodities speculation and food price crises: Regulation to reduce the risks of price volatility. Briefing Note 02, September. http://www.srfood.org/index.php/en/compo nent/content/article/894-food-commoditiesspeculation-and-foodprice-crises. Accessed 21 May 2014.

Institute for Agriculture and Trade Policy. 2008. Commodities market speculation: The risk to food security and agriculture. Minneapolis, MN: Institute for Agriculture and Trade Policy.

Irwin, S.H., D.R. Sanders, and R.P. Merrin. 2009. Devil or angel? The role of speculation in the recent commodity price boom (and bust). Journal of Agricultural and Applied Economics 41(2): 377-391.

Irwin, S.H., and D.R. Sanders. 2010. The impact of index and swap funds on commodity futures markets: Preliminary results. $O E C D$ 
Food, Agriculture and Fisheries Working Papers, No. 27, Paris: OECD.

Isakson, R. 2014. Financialization and the transformation of agrofood supply chain: A political economy. The Journal of Peasant Studies 41(6): 37-41.

Kerckhoffs, T., R. van Os, and M. Vander Stichele. 2010. Financing food: Financialisation and financial actors in agriculture commodity markets. Amsterdam: SOMO.

Kneen, B. 2002. Invisible giant: Cargill and its transnational strategies. London: Pluto Press.

Lander, C.D. 2016. Foreign Investment Adaptations to the Changing Political and Economic Environments of the Agro-Food Sector: A Case Study of Cargill Russia. Problems of Post-Communism $1-19$.

Lindsey, M. 2013. Black River commodity trading fund: Black River Asset Management. Interview with Jeff Drobny, chief investment officer, and Mark Schulze, senior portfolio manager. Risk.net Financial Risk Management News and Analysis, 17 June. http:// www.risk.net/hedge-funds-review/profile/2274857/black-rivercommodity-trading-fund-black-river-asset-management. Accessed 8 June 2014.

Lippert, J. 2011. Cargill defines food chain while assailing government hoarding. Bloomberg. http://www.bloomberg.com/news/ 2011-07-27/cargill-defines-food-chain-while-assailing-govern ment-hoarding.html. Accessed 8 May 2014.

Luyt, I. 2013. Emerging investment trends in primary agriculture: A review of equity funds and other foreign-led investments in the CEE and CIS region. [ebook]. Directions in Investment seriesN. 8. Rome, Italy: Food and Agriculture Organization of the United Nations. http://eastagri.org/publications/detail.asp?id=80. Accessed 5 Jan 2014.

Meyer, G. 2011. Commodity traders hit back at planned US futures curbs. Financial Times. 13 June. http://www.ft.com/intl/cms/s/0/ 0b747be0-95e3-11e0-ba20-00144feab49a.html\#axzz3pDMMF myp. Accessed 8 May 2014.
Murphy, S., D. Burch, and J. Clapp. 2012. Cereal secrets: The world's largest grain traders and global agriculture. Oxfam Research Reports.

Russi, L. 2013. Hungry capital: The financialization of food. Winchester: Zero Books.

Salerno, T. 2014. Capitalising on the financialisation of agriculture: Cargill's land investment techniques in the Philippines. Third World Quarterly 35(9): 1709-1727.

Shieber, J. 2013. Black River targets at least $\$ 400 M$ for second agriculture fund. http://pevc.dowjones.com/Article?an=DJFLBO $0020130715 \mathrm{e} 97 \mathrm{fbw} 4 \mathrm{ja} \& \mathrm{cid}=32135028 \&$ ctype $=$ ts $\&$ ReturnUrl $=$ http $\% 3 \mathrm{a} \% 2 \mathrm{f} \% 2$ fpevc.dowjones.com\%2fArticle $\% 3$ fan $\% 3 \mathrm{dDJFLB}$ O0020130715e97fbw4ja\%26cid\%3d32135028\%26ctype\%3dts. Accessed 21 June 2014.

Spratt, S. 2013. Food price volatility and financial speculation. Sussex: Future Agricultures.

United States House of Representatives. 2010. Dodd-Frank Wall Street Reform and Consumer Protection Act: Conference Report to Accompany H.R. 4173. 11th congress. 2nd session. Report 111-517, 29 June. Washington, DC: US Government.

van Dijk, B., G. Berntsen and I. Berget 2011. Speculate or integrate: Rethinking agricultural commodity markets. A.T. Kearney Issue Papers and Perspective. Chicago, IL: A.T. Kearney.

Whitford, D., and D. Burke. 2011. Cargill: Inside the quiet giant that rules the food business. Fortune. http://archive.fortune.com/2011/10/24/ news/companies/cargill_food_business.fortune/index.htm.

Tania Salerno is a Ph.D. candidate in the Anthropology and Sociology Department, University of Amsterdam. She is part of the research program, "(Trans)national Land Investments in Indonesia and the Philippines: Contested Control of Farm Land and Cash Crops", funded by NWO-WOTRO. Her research interests include agrarian development, land, financialized corporate agriculture, and the global food system. 